\title{
Penggunaan TID-ID untuk Menonton di Sinema XXI pada Masa Pandemi Covid-19
}

\section{The Use of TIX-ID to Watch Cinema XXI during the Covid-19 Pandemic}

\author{
Meylani Tuti ${ }^{1}$, Shilviana Jihan ${ }^{1}$ \\ 1)Program Studi Manajemen, STIE Pariwisata Internasional, Jakarta, Indonesia \\ *Corresponding Email: meylanituti@stein.ac.id
}

\begin{abstract}
Abstrak
Tujuan dari penelitian ini adalah untuk menganalisis pengaruh pengaruh e-commerce dan citra merek terhadap kepuasan konsumen melalui keputusan pembelian. Populasi dalam penelitian ini adalah pelanggan, yakni penonton film di Cinema XXI Jakarta Utara dan Bekasi Selatan yang menggunakan TIX ID lebih dari dua kali. Teknik pengambilan sampel menggunakan purposive sampling dengan menyebarkan google form pada 275 penonton yang membeli tiket menggunakan TIX-ID. Data telah diuji validitas dan reliabilitasnya. Metode analisis data adalah secara deskriptif dan kuantitatif. Analisis kuantitatif dilaksanakan dengan menggunakan Structural Equation Modeling (SEM). Hasil penelitian ini menunjukkan bahwa e-commerce berpengaruh terhadap keputusan pembelian dengan t-value 2,15, brand image berpengaruh terhadap keputusan pembelian dengan $t$ value 5,63, e-commerce berpengaruh terhadap kepuasan konsumen dengan $t$-value 1,97, citra merek berpengaruh terhadap kepuasan konsumen dengan t-value 2,56, keputusan pembelian berpengaruh terhadap kepuasan konsumen dengan $t$-value 3,07. Selain itu, tidak terdapat pengaruh tidak langsung yang signifikan antara e-commerce terhadap kepuasan konsumen melalui keputusan pembelian dengan $t$-value 1,72 , terdapat pengaruh tidak langsung antara citra merek terhadap kepuasan konsumen melalui keputusan pembelian dengan $t$-value 2,72.
\end{abstract}

Kata Kunci: E-Commerce, Citra Merek, Keputusan Pembelian, Kepuasan Pelanggan.

\section{Abstract}

The purpose of the study was to analyze the impact of the influence of e-commerce and brand image on customer satisfaction through purchase decisions. The population in this study are customer, namely film viewers at Cinema XXI North Jakarta and South Bekasi who use TIX ID more than twice. The sampling technique used purposive sampling by distributing google form on 275 viewers who bought tickets using TIX-ID. Data have been tested on the validity and reliability. The method data analysis is by using descriptive and quantitative. The quantitative analysis is conducted by using Structural Equation Modeling (SEM). The result of this study indicates that e-commerce influences purchase decisions by t-value of 2.15, brand image influences purchase decisions by $t$-value of 5.63, ecommerce influences customer satisfaction by the t-value of 1.97, brand image influences customer satisfaction by the $t$-value of 2.56, purchase decisions influence customer satisfaction by the $t$-value of 3.07. Additionally, there is no significant indirect effect between e-commerce on customer satisfaction through purchase decisions by the t-value of 1.72, there is an indirect effect between brand image on customer satisfaction through purchase decisions by the t-value of 2.72 .

Keywords: E-Commerce, Brand Image, Purchase Decisions, Customer Satisfaction.

How to Cite: Tuti, M., \& Jihan, S. (2021). Penggunaan TID-ID untuk Menonton di Sinema XXI pada Masa Pandemi Covid-19. JKBM (Jurnal Konsep Bisnis dan Manajemen). 7 (2): 215-226 
Tuti, M., \& Jihan, S. (2021). Penggunaan TID-ID untuk Menonton di Sinema XXI pada Masa Pandemi Covid-19

\section{PENDAHULUAN}

Perkembangan teknologi membuat hidup kita semakin mudah untuk berbelanja memesan tiket dan hotel, memesan makanan bahkan untuk menonton bioskop bisa dilakukan dengan mudah dari mana saja. Kemudahan ini menarik masyarakat untuk memenuhi kebutuhan atau keperluannya secara online termasuk untuk menikmati hiburan. Dunia bisnis memanfaatkan teknologi dalam menjalankan usahanya karena memberikan kemudahan baik bagi perusahaan maupun bagi konsumennya. Dalam dunia bisnis dikenal istilah e-commerce yaitu perdagangan yang dilakukan secara virual atau virtual marketplace (Strauss, Judy. \& Frost, 2014). E-commerce juga alat terpenting untuk diop-timalkan dalam pemasaran, seperti media sosial yang menyediakan fitur unik untuk mempromosikan dan menjual produk (Lestari, 2019). Selan-jutnya, $e$ commerce secara populer didefinisikan sebagai proses perdagangan dan pertukaran barang, jasa, atau informasi melalui media elektronik (Abdullah, Ramli, Bakodah, \& Othman, 2020). Artinya e-commerce sudah berlaku untuk jenis kegiatan bisnis lainnya dan tidak lagi terbatas pada transaksi produk (Zwass, 1996). Faktor yang pendukung e-commerce (Abdullah et al., 2020) adalah kegunaan situs, keamanan, informasi tentang produk atau layanan, penawaran insentif, kemudahan penggunaan dan kenyamanan sistem.

E-commerce banyak diterapkan di dunia bisnis, salah satunya bisnis entertainment. Hiburan dibutuhkan oleh orang-orang sibuk untuk melepas penat menonton di bioskop merupakan salah satu bentuk hiburan yang sederhana karena dapat dilakukan disela-sela kesibukan dan tidak mengeluarkan biaya yang tidak sedikit. Selama pandemi, semua aktivitas dibatasi oleh peraturan ketat, termasuk di bioskop. Selain mengurangi kapasitas hingga 50\% sebagai bentuk social distancing, penonton diwajibkan memakai masker dan membawa hand sanitizer. Selama pandemi, pemesanan tiket dipesan baik secara langsung atau melalui TIX-ID. Dalam menghadapi persaingan, bioskop XXI menggunakan TIX-ID sebagai alat untuk memesan tiket. Hal ini memudahkan pelanggan dalam memesan kapanpun dan di manapun dengan hanya menggunakan handphone.

Keputusan pembelian adalah ketika konsumen menentukan merek berdasarkan kesukaannya sebagai hasil masukan orang lain atau berada pada posisi tidak ada pilihan (Kotler \& Armstrong, 2008), atau bisa dikatakan ketika konsumen menghadapi alternatif-alternatif untuk dipilih bagi konsumen melakukan pembelian bukan hanya dipengaruhi oleh satu faktor namun ada berbagai faktor alternatif (Sangadji \& Sopiah., 2013). Tahapan dalam melakukan pembelian yaitu; pengenalan masalah, pencarian informasi, evaluasi alternatif, keputusan pembelian, dan perilaku pasca pembelian (Karimi, Papamichail, \& Holland, 2015). Perasaan senang atau kecewa sebagai hasil dari melakukan pembelian menimbulkan kepuasan (Budi, 2013). Kepuasan juga ditimbulkan oleh pengalaman ketika harapan sesuai dengan yang didapatkan (Mano \& Ollver, 2015; Susanto, Laksana, \& Prianka, 2019). Hal ini menunjukkan bahwa kepuasan merupakan penilaian akhir yang ditunjukkan secara emosional 
setelah pembelian (Minarti \& Segoro, 2014; Rusydi, 2017; Song, Wang, \& Han, 2019a).

Penggunaan TIX-ID membantu protokol kesehatan selama pandemi. Dengan menggunakan TIX-ID, pelanggan dapat melakukan pemesanan melalui ponsel dan menentukan tempat duduk yang diinginkan serta membaca review film yang ditonton. Penelitian sebelumnya menghasilkan temuan bahwa e-commerce berpengaruh positif dan signifikan terhadap keputusan pembelian (Nurjanah, Kurniati, \& Zunaida, 2019; Ramdhan, 2019). E-commerce juga berpengaruh positif dan signifikan terhadap kepuasan pelanggan (Lestari, 2019; Saputra, 2017). Dari uraian di atas diajukan hipotesis:

H1: e-commerce memiliki pengaruh positif terhadap keputusan pembelian pada XXI.

H2: e-commerce memiliki pengaruh positif terhadap kepuasan konsumen sinema XXI.

H3: e-commerce memiliki pengaruh positif terhadap keputusan pembelian dan kepuasan konsumen sinema XXI.

Bioskop yang sedang berkembang saat ini tidak hanya bioskop XXI tetapi juga bioskop lain seperti CGV, Cinépolis, Dakota Sinema, Platinum Cineplex, FLIX Sinema, dan New Star Cineplex. Sinema XXI merupakan bioskop pertama di Indonesia yang sudah dikenal secara luas. Citra merek yang kuat tidak menjadikan Sinema XXI bertahan dalam menghadapi perkembangan teknologi dan persaingan. Citra merek adalah ingatan merek yang melekat pada konsumen sehingga memungkinkan konsumen melakukan pembelian berulang (Rangkuti, 2009). Citra merek juga adalah persepsi yang melekat pada konsumen (A, Shimp, 2003). Citra merek adalah keyakinan yang dimi- liki konsumen (Song, Wang, \& Han, 2019b). Konsumen bergantung pada merek tersebut (Priansa, 2017). Pengukuran citra merek berdasarkan kekuatan (strength), keunikan (uniqueness), dan favourable (Keller, 2003).

Citra perusahaan dibangun oleh merek yang baik di mata konsumen. Semakin kuat citra merek perusahaan di benak pelanggan akan menyebabkan pelanggan membeli dan memiliki kepercayaan diri yang lebih kuat untuk loyal. Penelitian sebelumnya yang dilakukan oleh beberapa peneliti menemukan bahwa citra merek berpengaruh signifikan terhadap keputusan pembelian (Ardiantika \& Rachmi, 2017; Aziky \& Masreviastuti, 2018; Lubis \& Hidayat, 2017; Pahlevi \& Hadi, 2014; Pratiwi, Zaini, Niaga, \& Malang, 2018). Citra merek berpengaruh positif dan signifikan terhadap kepuasan (Putri \& Santoso, 2018; Rambe, Maksum, \& Jasin, 2017). Dari uraian di atas diajukan hipotesis:

H4: citra merek memiliki pengaruh positif terhadap keputusan pembelian pada Sinema XXI.

H5: citra merek memiliki pengaruh positif terhadap kepuasan konsumen Sinema XXI.

H6: citra merek memiliki pengaruh positif terhadap keputusan pembelian dan kepuasan konsumen Sinema XXI.

H7: keputusan pembelian memiliki pengaruh positif terhadap kepuasan konsumen Sinema XXI.

Penelitian terdahulu menunjukkan bahwa keputusan pembelian adalah faktor yang menimbulkan kepuasan pada konsumen, namun dalam penelitian sebelumnya yang dilakukan oleh Lukman menunjukkan bahwa keputusan pembelian tidak berpengaruh terhadap kepuasan konsumen (Lukman, 2014). Hal ini menarik untuk ditelaah 
lebih lanjut apakah keputusan pembelian pada sinema XXI mempengaruhi kepuasan. Tujuan dari penelitian ini adalah untuk mengetahui apakah $e$ commerce dan citra merek sinema XXI berperan dalam keputusan untuk menonton di sinema XXI dan apakah keputusan untuk menonton berpe- ngaruh pada kepuasan konsumen selama pandemi dengan melakukan survey pada beberapa Sinema XXI di wilayah kota Jakarta dan Bekasi. Dari uraian di atas kerangka penelitian dalam penelitian ini sebagai berikut:

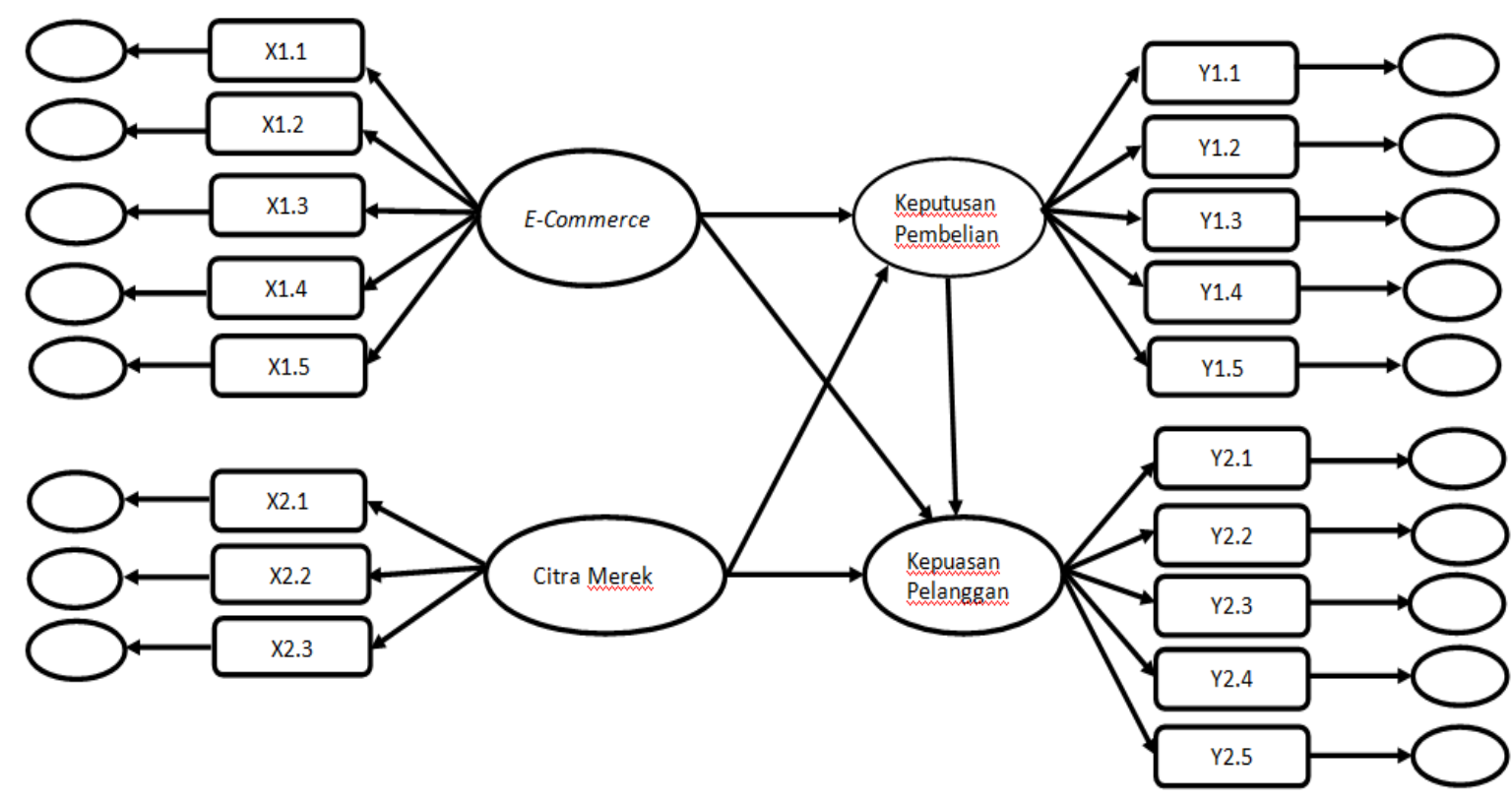

Gambar 1 Kerangka Berfikir

\section{METODE PENELITIAN}

Metode survey adalah metode yang digunakan dalam penelitian ini yang dilakukan untuk memperoleh informasi tentang pendapat responden. Model penelitian yang digunakan adalah SEM (Structural Equation Modeling) yang dioperasikan melalui program LISREL (Linear Structural Relationship) versi 8.80. Data yang digunakan berasal dari hasil angket yang dibagikan pada responden.

Bagian dari populasi adalah sampel, dan sampel yang dipilih hanyalah yang memiliki ciri sesuai dengan yang ditentukan sebelumnya (Siregar, 2013). Penentuan sample dalam penelitian ini menggunakan kriteria yang ditentukan terle- bih dahulu (purposive sampling) yaitu konsumen yang sudah melakukan pembelian tiket lebih dari dua kali dengan menggunakan TIX-ID.

Data diperoleh melalui penyebaran google form pada 275 penonton yang membeli tiket dengan TIX-ID di Sinema XXI yang terdiri dari Sinema XXI Koja Trade Mall Jakarta Utara sebanyak 63 responden, Sinema XXI Mall Kelapa Gading Jakarta Utara sebanyak 58 responden, Cinema XXI Mall Artha Gading Jakarta Utara sebanyak 43 responden, Sinema XXI Mall Metropolitan Bekasi Selatan sebanyak 52 responden, dan Sinema XXI Revo Town Bekasi Selatan sebanyak 59 responden dengan pembelian lebih dari dua kali dengan menggunakan TIX ID. Setelah melalui 
proses outliers, terbuang 52 responden sehingga data yang tersisa adalah 223 responden.

Metode analisis dalam penelitian ini menggunakan SEM (Structural Equation Model) dengan software Lisrel 8,7. Pada tahap awal data di uji outliers dengan menggunakan malahanobis untuk memastikan tidak terdapat pencilan data. Evaluasi model dilakukan dengan uji validitas) dan reliabilitas (measurement model dan uji kecocokan (Goodness of Fit Measurement). Langkah terkahir adalah evaluasi model structural dan signifikansi parameter dengan membandingkan t-value (Ghozali, 2016; Wijayanto, 2007; Yamin \& Kurniawan, 2009).

Penelitian ini adalah tipe penelitian yang bersifat explanatory research. Penelitian melibatkan Dosen di Fakultas Ekonomi dan Bisnis Universitas Pattimura. Berdasarkan data Dosen jumlah dosen di Fakultas Ekonomi dan Bisnis ini ada 107 dengan menggunakan teknik sampling acak sederhana dan rumus Slovin maka sampel penelitian ini adalah 52 responden. Metode statistik inferensial yang digunakan dalam penelitian ini adalah Partial Least Square (PLS)

\section{HASIL DAN PEMBAHASAN}

Berdasarkan deskripsi responden, mayoritas responden adalah perempuan dengan jumlah persentase 65,6\%, dan rentang usia mayoritas antara 21-30 tahun dengan jumlah persentase $68,1 \%$, Berdasarkan pekerjaan, mayoritas responden adalah pelajar/mahasiswa dengan jumlah persentase 60,5\%, dan mayoritas responden mendapatkan informasi melalui media sosial dengan jumlah 57\%, dengan frekuensi penggunaan TIX-ID sebanyak lebih dari 5 kali sebanyak $53,4 \%$.

Tabel 1 Deskripsi Responden

\begin{tabular}{|c|c|c|}
\hline Demografi Responden & Frekuensi & Persentase \\
\hline \multicolumn{3}{|l|}{ Jenis kelamin } \\
\hline Laki-Laki & 77 & 34,5 \\
\hline Perempuan & 146 & 65,6 \\
\hline \multicolumn{3}{|l|}{ Usia } \\
\hline$<20$ tahun & 51 & 22,9 \\
\hline $21-30$ tahun & 152 & 68,1 \\
\hline 31-40 tahun & 12 & 5,4 \\
\hline$>40$ tahun & 8 & 3,6 \\
\hline \multicolumn{3}{|l|}{ Pekerjaan } \\
\hline Swasta & 58 & 26 \\
\hline Pelajar/Mahasiswa & 135 & 60,5 \\
\hline PNS & 8 & 3,6 \\
\hline Wirausahawan & 22 & 9,9 \\
\hline \multicolumn{3}{|l|}{ Informasi TIX-ID } \\
\hline Teman & 64 & 28,7 \\
\hline Keluarga & 14 & 6,3 \\
\hline Media Sosial & 127 & 57 \\
\hline Website & 18 & 8 \\
\hline \multicolumn{3}{|l|}{ frekuensi Penggunaan TIX-ID } \\
\hline 2 kali & 25 & 11,2 \\
\hline 3-5 kali & 79 & 35,4 \\
\hline$>5$ kali & 119 & 53,4 \\
\hline
\end{tabular}

Data olah penulis 2021 
Tuti, M., \& Jihan, S. (2021). Penggunaan TID-ID untuk Menonton di Sinema XXI pada Masa Pandemi Covid-19

Tabel 2 Hasil Pengukuran Validitas dan Reliabilitas

\begin{tabular}{|c|c|c|c|c|c|c|c|}
\hline Indikator & $\begin{array}{l}\text { Standarized } \\
\text { Loading }\end{array}$ & $\begin{array}{c}\text { Error } \\
\text { Variance }\end{array}$ & t- Statistik & Error & $\begin{array}{c}\text { Constuct } \\
\text { Reliability }\end{array}$ & $\begin{array}{c}\text { Average } \\
\text { Variance } \\
\text { Extracted }\end{array}$ & $\begin{array}{c}\text { Discriminant } \\
\text { Validity }\end{array}$ \\
\hline $\mathrm{X} 1.1$ & 0.91 & 0.17 & 27.92 & \multirow{5}{*}{0.91} & \multirow{5}{*}{0.96} & \multirow{5}{*}{0.82} & \multirow{5}{*}{0.91} \\
\hline $\mathrm{X} 1.2$ & 0.86 & 0.26 & 21.34 & & & & \\
\hline $\mathrm{X} 1.3$ & 0.85 & 0.27 & 22.82 & & & & \\
\hline X1.4 & 0.93 & 0.14 & 29.69 & & & & \\
\hline $\mathrm{X} 1.5$ & 0.96 & 0.07 & 38.57 & & & & \\
\hline $\mathrm{X} 2.1$ & 0.98 & 0.04 & 30.88 & \multirow{6}{*}{0.71} & \multirow{6}{*}{0.98} & \multirow{6}{*}{0.88} & \multirow{6}{*}{0.94} \\
\hline $\mathrm{X} 2.2$ & 0.95 & 0.09 & 38.00 & & & & \\
\hline $\mathrm{X} 2.3$ & 0.96 & 0.09 & 35.81 & & & & \\
\hline $\mathrm{X} 2.4$ & 0.95 & 0.09 & 39.28 & & & & \\
\hline $\mathrm{X} 2.5$ & 0.91 & 0.18 & 24.95 & & & & \\
\hline $\mathrm{X} 2.6$ & 0.88 & 0.22 & 22.11 & & & & \\
\hline Y1.1 & 0.92 & 0.15 & 28.18 & \multirow{5}{*}{0.53} & \multirow{5}{*}{0.98} & \multirow{5}{*}{0.89} & \multirow{5}{*}{0.94} \\
\hline $\mathrm{Y} 1.2$ & 0.95 & 0.09 & 30.68 & & & & \\
\hline Y1.3 & 0.95 & 0.1 & 38.24 & & & & \\
\hline Y1.4 & 0.96 & 0.08 & 38.47 & & & & \\
\hline Y1.5 & 0.94 & 0.11 & 34.60 & & & & \\
\hline Y2.1 & 0.89 & 0.2 & 28.59 & \multirow{5}{*}{0.56} & \multirow{5}{*}{0.98} & \multirow{5}{*}{0.89} & \multirow{5}{*}{0.94} \\
\hline Y2.2 & 0.97 & 0.06 & 34.68 & & & & \\
\hline Y2.3 & 0.96 & 0.09 & 33.11 & & & & \\
\hline Y2.4 & 0.93 & 0.13 & 28.42 & & & & \\
\hline Y2.5 & 0.96 & 0.08 & 35.13 & & & & \\
\hline
\end{tabular}

Tabel 2 menunjukkan bahwa model lebih rendah dari discriminant Validity. Confirmapengukuran dinyatakan baik, hal ini dibuktikan tory Factor Analyses digunakan untuk menguji kedengan nilai $C R \geq 0,70$, nilai $\mathrm{VE} \geq 0,50$, nilai AVE cocokan model dan hasilnya menunjukkan bahwa (Average Error Variant) 0,87 $\geq 0,50$, dan nilai VE model sudah fit seperti terlihat pada tabel 3 : .

Tabel 3 Confirmatory Factor Analyses

\begin{tabular}{lcc}
\hline UKURAN Goodness of Fit & Hasil & Keterangan \\
\hline RMSEA & 0.063 & Good Fit \\
\hline ECVI & 1.98 & Good Fit \\
\hline NFI & 0.99 & Good Fit \\
\hline NNFI & 0.99 & Good Fit \\
\hline CFI & 0.99 & Good Fit \\
\hline IFI & 0.99 & Good Fit \\
\hline RFI & 0.99 & Good Fit \\
\hline RMR & 0.0072 & Good Fit \\
\hline Standardized RMR & 0.029 & Good Fit \\
\hline GFI & 0.59 & Poor Fit \\
\hline AGFI & 0.50 & Poor Fit \\
\hline Sumber: Data Lisrel, 2021 & &
\end{tabular}

Didapatkan semua nilai uji kecocokan 0,99 , $\mathrm{RMR}=0,0072$, dan standardized $\mathrm{RMR}=$ CFA Measurement Model yang good fit, ditun- 0,029. Hanya GFI dan AGFI yang menunjukkan jukkan dengan hasil RMSEA sebesar 0,063, NFI = hasil Poor Fit. $0,99, \mathrm{NNFI}=0,99, \mathrm{CFI}=0,99, \mathrm{IFI}=0,99, \mathrm{RFI}=$ 


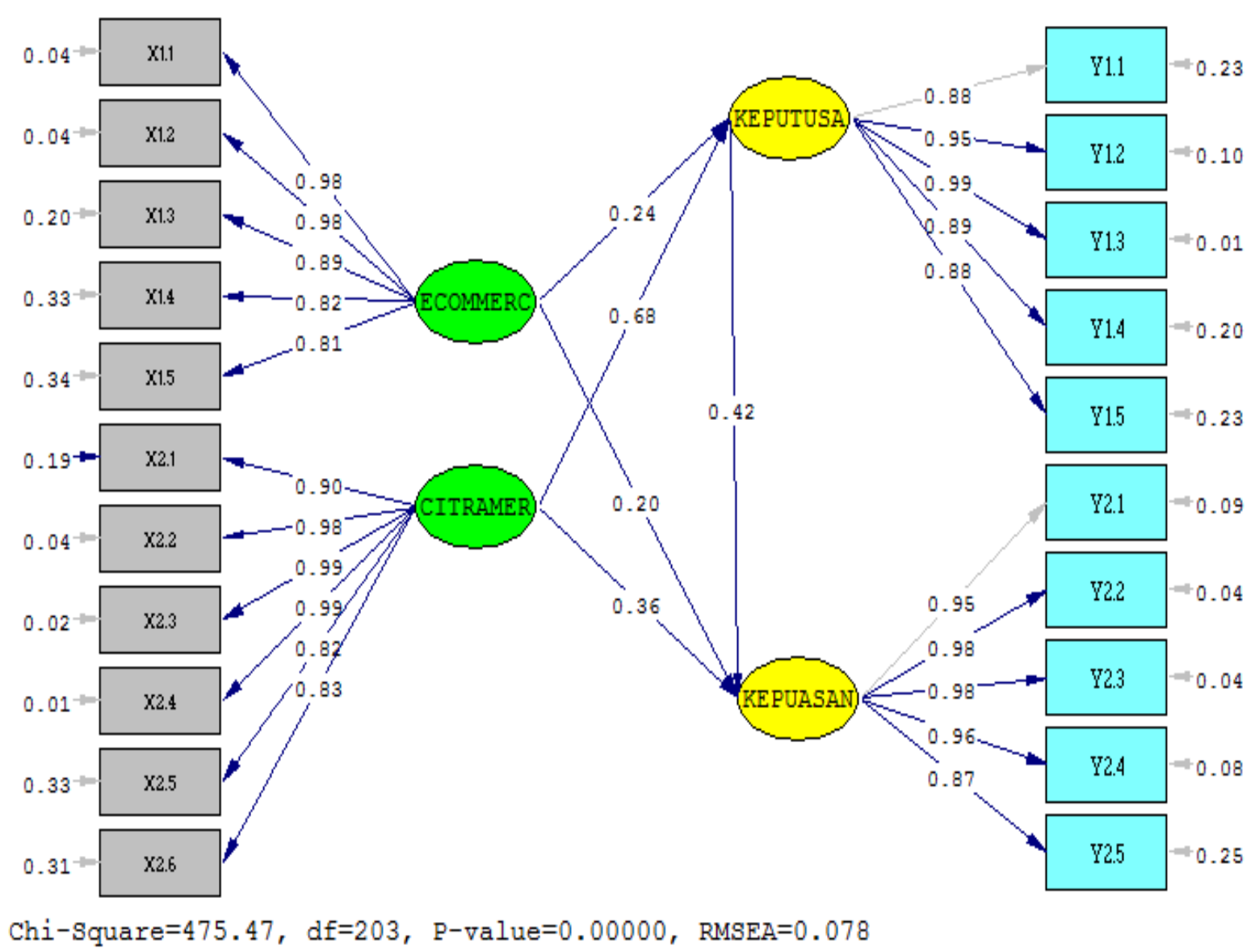

Gambar 1: Structural Equation Modeling (SEM) berdasarkan Standarized Solution Sumber: Output LISREL 8.70

Hasil Standarized loading factor di atas Confirmatory Factor Analyses memenuhi kriteria sudah valid dengan nilai standarized loading goodness of fit untuk full model SEM hanya nilai factor bernilai $\geq 0$,50. Demikian juga dengan hasil GFI dan AGFI yang menunjukkan Poor Fit.

Tabel 4 T-value dan Koefisien pada Model Struktural

\begin{tabular}{|c|c|c|c|c|}
\hline Path & Estimasi & $\begin{array}{c}\text { Nilai- } \\
t\end{array}$ & $\begin{array}{c}\text { Nilai } \\
\text { Kritis }\end{array}$ & Kesimpulan \\
\hline E-commerce (X1) $\rightarrow$ Keputusan Pembelian (Y1) & 0.24 & 2.15 & 1.96 & Signifikan \\
\hline E-commerce (X1) $\rightarrow$ Kepuasan Pelanggan (Y2) & 0.2 & 1.97 & 1.96 & Signifikan \\
\hline $\begin{array}{l}\text { E-commerce (X1) } \rightarrow \text { Keputusan Pembelian (Y1) } \rightarrow \text { Kepuasan } \\
\text { Pelanggan (Y2) }\end{array}$ & 0.1 & 1.72 & 1.96 & $\begin{array}{c}\text { Tidak } \\
\text { Signifikan }\end{array}$ \\
\hline Citra Merek (X2) $\rightarrow$ Keputusan Pembelian (Y1) & 0.68 & 5.63 & 1.96 & Signifikan \\
\hline Citra Merek (X2) $\rightarrow$ Kepuasan Pelanggan (Y2) & 0.36 & 2.56 & 1.96 & Signifikan \\
\hline $\begin{array}{l}\text { Citra Merek (X2) } \rightarrow \text { Keputusan Pembelian (Y1) } \rightarrow \text { Kepuasan } \\
\text { Pelanggan (Y2) }\end{array}$ & 0.29 & 2.72 & 1.96 & Signifikan \\
\hline Keputusan Pembelian (Y2) $\rightarrow$ Kepuasan Pelanggan (Y1) & 0.42 & 3.07 & 1.96 & Signifikan \\
\hline
\end{tabular}

\section{PEMBAHASAN}


E-commerce adalah bagian dari e-bisnis di mana transaksi dilakukan secara online termasuk menampilkan produk/pelayanan yang ditawarkan (Strauss, Judy. \& Frost, 2014). TIX-ID menawarkan informasi yang lengkap tentang film lengkap seperti film yang akan di tayangkan, cuplikan film, sinopsis, berita tentang dunia film, lokasi bioskop. dan kemudahan untuk pemesanan tiket di TIX ID seperti film yang sedang ditayangkan, jam tayang, harga, durasi film, dan kursi yang diinginkan, dan transaksi pembayaran yang mudah melalui e-banking, dan dana.

Selain itu juga menyediakan informasi promosi yang ditawarkan seperti potongan harga pembelian kedua, dan potongan harga dengan pembayaran menggunakan e-banking, dan adanya keamanan bahwa identitas atau data yang digunakan ketika mendaftar tidak diketahui orang lain karena menggunakan kode serta menggunakan password untuk login. tampilan TIX ID yang simpel dengan latar putih dan saat pemilihan kursi warna kursi kosong dan terisi berbeda jika kosong berwarna biru tua sedangkan terisi berwarna abu-abu, dan bukti transaksi dilengkapi dengan barcode dan kode transaksi sehingga aman. e-commerce dianggap sebagai saluran terpenting yang harus dioptimalkan, dan bahkan media sosial, seperti line, facebook, dan instagram, menyediakan fitur unik yang membantu individu tidak hanya mempromosikan tetapi juga menjual produk mereka online (Lestari, 2019).

Fasilitas yang disediakan menimbulkan kepuasan pada penggunanya. Kepuasan adalah ketika keinginan konsumen terpenuhi oleh penyedia produk/layanan (Mano \& Ollver, 2015).
Kepuasan terjadi setelah pasca pembelian (Song et al., 2019b). Penggunaan TIX-ID sesuai diterapkan pada kondisi pandemik sekarang ini untuk mengurangi kerumunan pada saat pembelian tiket di loket dan pemberian informasi pengaturan kapasitas 50\% pada konsumen sebelum sampai ke bioskop. Penelitian sebelumnya menghasilkan kesimpulan adanya pengaruh $e$ commerce terhadap keputusan pembelian (Nurjanah et al., 2019; Putra \& Wulandari, 2015) . Ecommerce berpengaruh terhadap kepuasan konsumen (Puji Lestari, 2018; Saputra, 2017), dan terhadap kepuasan pelanggan (Puji Lestari, 2018; Saputra, 2017). Dalam penelitian ini, e-commerce tidak memiliki pengaruh terhadap kepuasan melalui keputusan pembelian dengan nilai t-value $<1,96$.

Sinema XXI pelopor bioskop pertama di Indonesia, sudah lebih dari 32 tahun berdiri. Cinema XXI memiliki suatu keunikan seperti suasana, dekorasi, seragam staff yang sama di Sinema XXI manapun. Nama Sinema XXI yang mudah di ucapkan dan di ingat serta sudah lama berdiri menjadikan Sinema XXI melekat di benak masyarakat, sehingga jika mendengar kata bioskop yang terlintas adalah Sinema XXI. Hal ini membuat pelanggan memilih Sinema XXI ketika ingin menonton film di bioskop. Pengukuran citra merek berdasarkan strength, uniqueness, dan favourable (Keller, 2003). Citra merek dari Sinema XXI sudah terkenal di Indonesia. Sinema XXI memiliki citra yang baik sehingga membuat Cinema XXI selalu melekat di benak masyarakat Indonesia. Kesan yang baik diberikan oleh Sinema XXI untuk pelanggan. Kesan ini tercipta dari kualitas produk, fasilitas, keunikan, dan nama Sinema XXI 
yang mudah diingat. Citra merek adalah ingatan merek yang melekat pada konsumen sehingga memungkinkan konsumen melakukan pembelian berulang (Rangkuti, 2009). Persepsi yang melekat pada konsumen (A, Shimp, 2003). Citra Merek adalah berapa besarnya nilai perusahaan dalam benak pelanggan (Priansa, 2017).

Menonton film di bioskop kini menjadi trend, dan film kini semakin berkembang baik film Indonesia maupun film luar negeri. Sinema XXI menjamin kualitas audio dan visual yang berkelas, dan kualitas pelayanan yang baik di semua Sinema XXI. Melakukan pembelian bagi konsumen dipengaruhi berbagai pertimbangan yang terkait satu sama lain (Priansa, 2017). Evaluasi pasca pembelian adalah hal yang menentukan kepuasan pelanggan, pengalaman yang dimiliki konsumen setelah melakukan pembelian akan membuat konsumen memberikan respon suka atau tidak dan puas atau tidak (Song, Wang, \& Han, 2019c). Penelitian sebelumnya menunjukkan bahwa citra merek memiliki pengaruh terhadap keputusan pembelian (Ardiantika \& Rachmi, 2017; Aziky \& Masreviastuti, 2018; Lubis \& Hidayat, 2017; Pahlevi \& Hadi, 2014; Pratiwi et al., 2018). Citra merek memiliki pengaruh terhadap kepuasan konsumen (Putri \& Santoso, 2018; Rambe et al., 2017).

Nilai koefisien korelasi parsial positif menunjukkan searah, hal ini menggambarkan hubungan yang sangat kuat antara variabel $e$-commerce dan citra merek, dengan keputusan pembelian dan kepuasan.
Dalam penelitian ini keputusan pembelian dibentuk oleh e-commerce dan citra merek sebesar 0,81 (81\%), hal ini sesuai dengan penelitian dari (Nurjanah et al., 2019; Putra \& Wulandari, 2015; Ramdhan, 2019) yang menunjukkan bahwa e-commerce merupakan salah satu faktor yang membentuk keputusan konsumen untuk membeli. Faktor lainnya yaitu citra merek yang juga membentuk keputusan konsumen dalam membeli (Ardiantika \& Rachmi, 2017; Aziky \& Masreviastuti, 2018; Lubis \& Hidayat, 2017; Pahlevi \& Hadi, 2014; Pratiwi et al., 2018). Sisanya sebesar 0,19 (19\%) dibentuk oleh variabel yang tidak dijelaskan dalam model penelitian ini, seperti: kualitas pelayanan, kualitas produk, lokasi, dan lain-lain.

Kepuasan konsumen dibentuk oleh e-commerce, citra merek, dan keputusan pembelian sebesar 0,85 (85\%), hal ini sesuai dengan penelitian dari (Lestari (2018); Saputra \& Wongsosudono (2017)) yang menunjukkan bahwa e-commerce merupakan salah satu faktor yang membentuk kepuasan pelanggan. Faktor yang juga membentuk kepuasan pelanggan adalah citra merek (Putri \& Santoso, 2018; Rambe et al., 2017). Sedangkan faktor lain yang membentuk kepuasan pelanggan adalah keputusan pembelian (Akbar \& Haryoko, 2020; Rahmat, 2015; Santoso, 2016; Sinaga, Irianto, \& Widiyanti, 2017; Welsa \& Khoironi, 2019). Sisanya sebesar 0,15 (15\%) dibentuk oleh variabel yang tidak dijelaskan dalam model penelitian ini, seperti: kualitas pelayanan, kualitas produk, lokasi, dan lain-lain.

Tabel 5 Korelasi (r) dan Determinasi $\left(\mathrm{R}^{2}\right)$

\begin{tabular}{|c|c|c|c|}
\hline Path & Korelasi & Determinasi & Kesimpulan \\
\hline $\begin{array}{l}\text { E-commerce }\left(\mathrm{X}_{1}\right) \rightarrow \text { Keputusan } \\
\text { Pembelian }\left(\mathrm{Y}_{1}\right)\end{array}$ & 0.85 & \multirow[t]{2}{*}{0.81} & Sangat Kuat \\
\hline Citra Merek $\left(\mathrm{X}_{2}\right) \rightarrow$ Keputusan & 0.89 & & Sangat Kuat \\
\hline
\end{tabular}




\begin{tabular}{lllll}
\hline Pembelian $\left(\mathrm{Y}_{1}\right)$ & & & \\
\hline $\begin{array}{l}\text { E-commerce }\left(\mathrm{X}_{1}\right) \rightarrow \text { Kepuasan } \\
\text { Pelanggan }\left(\mathrm{Y}_{2}\right)\end{array}$ & 0.88 & & Sangat Kuat \\
\hline $\begin{array}{l}\text { Citra Merek }\left(\mathrm{X}_{2}\right) \rightarrow \text { Kepuasan } \\
\text { Pelanggan }\left(\mathrm{Y}_{2}\right)\end{array}$ & 0.91 & 0.85 & & Sangat Kuat \\
\hline $\begin{array}{l}\text { Keputusan Pembelian }\left(\mathrm{Y}_{1}\right) \rightarrow \\
\text { Kepuasan Pelanggan }\left(\mathrm{Y}_{2}\right)\end{array}$ & 0,91 & & & Sangat Kuat \\
\hline
\end{tabular}

Sumber: Data Lisrel, 2021

\section{SIMPULAN}

Dari hasil penelitian ini, sinema XXI sebagai bioskop tertua di Indonesia mampu membuat pelanggannya tetap kembali walaupun banyak Sinema lain yang muncul dengan tema dan fasilitas yang berbeda karena adanya citra merek yang sudah melekat pada konsumennya. Untuk mempertahankan diri di tengah persaingan industri bioskop, Sinema XXI beradaftasi dengan menggunakan teknologi yang memudahkan bagi penggunanya. TIX-ID mudah digunakan bagi semua kalangan usia, hal ini terlihat dari rentangan usia responden yang meliputi usia muda sampai tua. Keberadaanya terutama saat pandemik seperti saat ini membantu pelanggan yang ingin tetap menikmati hiburan ditengah pandemik dengan rasa aman karena tidak perlu berdesakan ketika melakukan pemesanan tiket dan dapat mengetahui kapasitas tiket yang tersedia sebelum datang ke bioskop.

\section{DAFTAR PUSTAKA}

A, Shimp, T. (2003). Periklanan Promosi \& Aspek Tambahan Komunikasi Pemasaran. Jakarta: Erlangga.

Abdullah, L., Ramli, R., Bakodah, H. O., \& Othman, M. (2020). Developing a causal relationship among factors of e-commerce: A decision making approach. Journal of King Saud University Computer and Information Sciences, 32(10), 1194-1201.

https://doi.org/10.1016/j.jksuci.2019.01.002

Akbar, M. F., \& Haryoko, U. B. (2020). Pengaruh Promosi Dan Harga Terhadap Keputusan Pembelian Dan Dampaknya Terhadap Kepuasan Pelanggan Pada Alfamart Cabang Cikokol
Tangerang. Jurnal Ekonomi Efektif, 2(2), 280-286. https://doi.org/10.32493/jee.v2i2.4170

Ardiantika, D. B. C., \& Rachmi, A. (2017). Pengaruh Inovasi Produk dan Brand Image Terhadap Keputusan Pembelian Pada Olivia Cake And Bakery Mojokerto. Jurnal Aplikasi Bisnis, 3(1), 6.

Aziky, A., \& Masreviastuti. (2018). PENGARUH PERIKLANAN DAN CITRA MEREK TERHADAP KEPUTUSAN PEMBELIAN PRODUK ECOMMERCE Shopee.co.id. J A B Jurnal Aplikasi Bisnis, 4.

Budi, A. P. (2013). Manajemen Marketing Perhotelan. Yogyakarta: ANDI OFFSET.

Ghozali, I. (2016). Aplikasi Analisis Multivariete Dengan Program IBM SPSS 23 (Edisi 8). Cetakan ke VIII. Semarang: Universitas Diponegoro.

Karimi, S., Papamichail, K. N., \& Holland, C. P. (2015). The effect of prior knowledge and decisionmaking style on the online purchase decisionmaking process: A typology of consumer shopping behaviour. Decision Support Systems, 77, 137-147. https://doi.org/10.1016/j.dss.2015.06.004

Keller, K. L. (2003). Strategic branding manajemen building, and managing brand equity. New Jersey: Pearson Education. New.

Kotler, P., \& Armstrong, G. (2008). Prinisp - prinsip manajemen pemasaran, (12th ed.). Jakarta: Erlangga.

Lestari, D. (2019). Measuring e-commerce adoption behaviour among gen-Z in Jakarta, Indonesia. Economic Analysis and Policy, 64, 103-115. https://doi.org/10.1016/j.eap.2019.08.004

Lubis, D. I. D., \& Hidayat, R. (2017). Pengaruh Citra Merek dan Harga terhadap Keputusan Pembelian pada Sekolah Tinggi Ilmu Manajemen Sukma Medan. Jurnal Ilman, 5(1), 15-24. https://doi.org/2355-1488

Lukman, M. D. (2014). Analisis Pengaruh Ekuitas Merek Terhadap Keputusan Pembelian Dan Kepuasan Konsumen Produk Teh Botol Sosro Kemasan Kotak. Jurnal Administrasi Bisnis, 10(1), 64-81. https://doi.org/10.26593/jab.v10i1.1222.

Mano, H., \& Ollver, R. L. (2015). Assessing the Dimensionality and Structure of the Consumption Experience: Evaluation, Feeling, and Satisfaction, 20(December 1993), 451-466. Retrieved from http://jcr.oxfordjournals.org/

Minarti, S. N., \& Segoro, W. (2014). The Influence of 
Customer Satisfaction, Switching Cost and Trusts in a Brand on Customer Loyalty - The Survey on Student as im3 Users in Depok, Indonesia. Procedia - Social and Behavioral Sciences, 143, 1015-1019.

https://doi.org/10.1016/j.sbspro.2014.07.546

Nurjanah, S. F., Kurniati, R. R., \& Zunaida, D. (2019). Pengaruh E-commerce terhadap Keputusan Pembelian pada Belanja Online Shopee (Studi pada Konsumen Belanja Online Mahasiswa Universitas Islam Malang). Jurnal Ilmu Administrasi Niaga/Bisnis, 8(3), 154-162. Retrieved from http://riset.unisma.ac.id/index.php/jiagabi/articl e/view/3572

Pahlevi, A. C., \& Hadi, M. (2014). Pengaruh Brand Image dan Kualitas Produk terhadap Keputusan Pembelian Produk Shampo Pantene. Jurnal Aplikasi Bisnis, 8(1), 55-61. Retrieved from http://jab.polinema.ac.id/index.php/jab/article/ view/50

Pratiwi, N. T., Zaini, A., Niaga, A., \& Malang, P. N. (2018). Pengaruh Integrated Marketing Communication ( Imc ) , Public Relations, Dan Citra Merek Terhadap Keputusan, 49-53.

Priansa, D. J. (2017). Komunikasi Pemasaran Terpadu. Bandung: CV Pustaka Setia.

Puji Lestari, F. A. (2018). Pengaruh Web E-Commerce, Kualitas Produk dan Kualitas Layanan terhadap Kepuasan Konsumen. Sosio E-Kons, 10(1), 87. https://doi.org/10.30998/sosioekons.v10i1.241 1

Putra, H. P., \& Wulandari, A. (2015). PENGARUH PENERAPAN E-COMMERCE ( Studi Kasus Pada Pengguna Steam Valve ). Jurnal Ecodemica, III(2), 446-454.

Putri, D. G. D., \& Santoso, S. B. (2018). Analisis Pengatuh Kualitas Jasa, Nilai Yang Dirasakan, Citra Merek Melalui Kepuasan Pelanggan Terhadap Loyalitas Pelanggan (Studi pada PT. Pos Indonesia(Persero)). Diponegoro Journal of Management, 7, 1-13.

Rahmat, H. (2015). Pengaruh Kepuasan Konsumen Terhadap Keputusan Pembelian Lampu Philips (Studi Kasus Pada Mahasiswa Telkom University). E c o d Emi c A ., III(1), 305-310. Retrieved from https://doaj.org/article/700ed6e64b1941608a3 db96cecf2ecd7

Rambe, N., Maksum, C., \& Jasin, M. (2017). Pengaruh Pelayanan, Citra Merek Dan Harga Terhadap Pebelian Ulang Melalui Keputusan Pelanggan Dan Word Of Mouth. Ekobisman, 1(3), 241-261.

Ramdhan, J. M. (2019). Pengaruh Media Sosial Dan ECommerce Terhadap Keputusan Pembelian Distro House of Smith. Jurnal Manajemen Dan Bisnis, 03(01), 534-544.

Rangkuti, F. (2009). Strategi Promosi Yang Kreatif \& Analisis Kasus Integrated Marketing
Communication. Jakarta: Gramedia.

Rusydi, M. (2017). Customer Excellence. Yogyakarta: Gosyen Publishing.

Sangadji, E. M., \& Sopiah. (2013). Perilaku Konsumen. Yogyakarta: ANDI OFFSET.

Santoso, I. (2016). Jurnal Manajemen Teknologi Indonesian Journal for the Science of Management. Jurnal Manajemen Teknologi, 15(1), 94-109. Retrieved from http://journal.sbm.itb.ac.id

Saputra, A. (2017). Analisis Pengaruh Penerapan ECommerce Dan Kualitas. Manajemen Bisnis STIE IBBI, 27(1).

Sinaga, O. S., Irianto, H., \& Widiyanti, E. (2017). Pengaruh Word of Mouth Terhadap Keputusan Pembelian Dan Kepuasan Konsumen (Studi Pada Konsumen Rumah Teh Ndoro Donker Kemuning). Agista, 5(1), 80-88.

Song, H. J., Wang, J. H., \& Han, H. (2019a). Effect of image, satisfaction, trust, love, and respect on loyalty formation for name-brand coffee shops. International Journal of Hospitality Management, 79(December 2018), 50-59. https://doi.org/10.1016/j.ijhm.2018.12.011

Song, H. J., Wang, J. H., \& Han, H. (2019b). Effect of image, satisfaction, trust, love, and respect on loyalty formation for name-brand coffee shops. International Journal of Hospitality Management, 79(June 2018), 50-59. https://doi.org/10.1016/j.ijhm.2018.12.011

Song, H. J., Wang, J. H., \& Han, H. (2019c). Effect of image, satisfaction, trust, love, and respect on loyalty formation for name-brand coffee shops. International Journal of Hospitality Management, 79(June 2018), 50-59. https://doi.org/10.1016/j.ijhm.2018.12.011

Strauss, Judy. \& Frost, R. (2014). E Marketing. Kolkata: Pearson Education.

Susanto, A., Laksana, P. A., \& Prianka, W. G. (2019). Pengaruh Brand Image Terhadap Keputusan Berkunjung Wisatawan Nusantara Ke Sari Ater Hotel \& Resort, Subang. Jurnal Kepariwisataan: Destinasi, Hospitalitas Dan Perjalanan, 3(2), 8897. https://doi.org/10.34013/jk.v3i2.34

Welsa, H., \& Khoironi, M. (2019). Pengaruh Kualiatas Layanan dan Store Atmosphere Terhadap Kepuasan Pelanggan Melalui Keputusan Pembelian Sebagai Variabel Intervening ( Studi Kasus Pada Konsumen di Restoran Toean Watiman Yogyakarta ) Henny Welsa Muhamad Khoironi. Ebbank, 10(1), 1-16.

Wijayanto, S. H. (2007). Struktural Equation Model. Jakarta: GRAHA ILMU.

Yamin, S., \& Kurniawan, H. (2009). SPSS Complete:Teknik Analisis. Statistik Terlengkap Dengan Software SPSS. Jakarta: Salemba Infotek.

Zwass, V. (1996). Electronic commerce: Structures and issues. International Journal of Electronic Commerce, 1(1), 3-23. 
Tuti, M., \& Jihan, S. (2021). Penggunaan TID-ID untuk Menonton di Sinema XXI pada Masa Pandemi Covid-19 https://doi.org/10.1080/10864415.1996.11518 273 